\title{
Cardiomyocyte death: mechanisms and translational implications
}

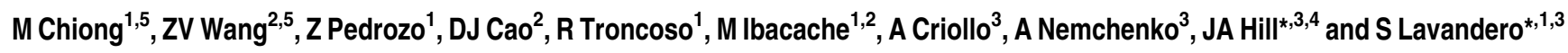

Cardiovascular disease (CVD) is the leading cause of morbidity and mortality worldwide. Although treatments have improved, development of novel therapies for patients with CVD remains a major research goal. Apoptosis, necrosis, and autophagy occur in cardiac myocytes, and both gradual and acute cell death are hallmarks of cardiac pathology, including heart failure, myocardial infarction, and ischemia/reperfusion. Pharmacological and genetic inhibition of autophagy, apoptosis, or necrosis diminishes infarct size and improves cardiac function in these disorders. Here, we review recent progress in the fields of autophagy, apoptosis, and necrosis. In addition, we highlight the involvement of these mechanisms in cardiac pathology and discuss potential translational implications.

Cell Death and Disease (2011) 2, e244; doi:10.1038/cddis.2011.130; published online 22 December 2011

Subject Category: Internal Medicine

\section{Cardiac Myocyte Death in the Pathogenesis of Disease}

The heart is an organ with limited capacity for regeneration and repair; hence, it is susceptible to numerous stresses and must respond to these insults in order to adapt to everchanging workload demands. Cell death, either progressive or acute, is a hallmark characteristic of various cardiac diseases, including heart failure (HF), myocardial infarction (MI), and ischemia/reperfusion (I/R; Figure 1). ${ }^{1}$ Now, at the turn of the 21st century, however, cardiovascular disease (CVD) still accounts for more than one-third of all human mortality and remains the leading cause of death worldwide. All three types of cell death, autophagic cell death, apoptosis, and necrosis, have been observed during progression of heart disease. ${ }^{1}$

\section{Autophagy}

One of the key cellular pathways that mediate stress-induced adaptation and damage control is macroautophagy (termed autophagy in this review). Autophagy is a highly conserved process of delivery of intracellular components, including mitochondria and long-lived macromolecules, via a doublemembrane structure (autophagosome) to lysosomes for degradation. ${ }^{2}$ In eukaryotic cells ${ }^{2}$ and in cardiac myocytes, ${ }^{3}$ starvation/nutrient deprivation, hypoxia, reactive oxygen species (ROS), damaged organelles, and protein aggregates have each been shown to induce autophagy in a mammalian target of rapamycin (mTOR)-dependent process. Similarly, mTOR-independent autophagy has been reported; cytokines, which do not exist in yeast, converge on type III phosphatidylinositol 3-kinase to induce autophagy. ${ }^{4}$

\section{Autophagy in Response to Ischemia and I/R \\ More than $95 \%$ of the energy required for cardiac myocyte function is derived from oxidative phosphorylation. Interrup- tion of blood flow to the myocardium disrupts oxygen supply, triggering rapid declines in ATP and increased AMP/ ATP ratios. Autophagy, as a pro-survival mechanism that replenishes energy under stress conditions, is activated. Ischemia/hypoxia induces autophagy in vivo and in vitro in most, ${ }^{5,6}$ although not all, ${ }^{7}$ studies. The two pathways responsible for ischemia/hypoxia-induced autophagy involve either $\mathrm{BNIP3}^{8}$ or $\mathrm{AMPK}^{9}$ In a mouse model expressing dominant-negative AMPK in cardiac myocytes, the auto- phagic response to ischemia was attenuated, leading to larger}

\footnotetext{
${ }^{1}$ Centro Estudios Moleculares de la Celula, Departamento de Bioquimica y Biología Molecular, Facultad de Ciencias Quimicas y Farmaceuticas and Facultad de Medicina, Universidad de Chile, Santiago, Chile; ${ }^{2}$ Departamento de Anestesiologia, Facultad de Medicina, Pontificia Universidad Catolica de Chile, Santiago, Chile; ${ }^{3}$ Division of Cardiology, Department of Internal Medicine (Cardiology), University of Texas Southwestern Medical Center, Dallas, TX, USA and ${ }^{4}$ Department of Molecular Biology, University of Texas Southwestern Medical Center, Dallas, TX, USA

${ }^{*}$ Corresponding authors: S Lavandero, Centro Estudios Moleculares de la Celula, Facultad de Ciencias Quimicas y Farmaceuticas and Facultad de Medicina, Universidad de Chile, Olivos 1007, Santiago 8380492, Chile. Tel: + 562 9782919; Fax: + 562 9782912; E-mail: slavander@uchile.cl

or JA Hill, Division of Cardiology, Department of Internal Medicine (Cardiology), University of Texas Southwestern Medical Center, NB11.200, 6000 Harry Hines Boulevard, Dallas, TX 75390, USA. Tel: 214648 1400; Fax: 214648 1450; E-mail: joseph.hill@utsouthwestern.edu

${ }^{5}$ These authors contributed equally to this work.

Keywords: apoptosis; autophagy; cardiovascular diseases; heart; necrosis

Abbreviations: AIF, apoptosis-inducing factor; ARC, apoptosis repressor with caspase recruitment domain; ATH, atherosclerosis; BID, BCL2-interacting protein; $\mathrm{BM}$, bone marrow; C, cardiomyopathy; casp, caspase; CHF, congestive heart failure; CVD, cardiovascular disease; cyto $c$, cytochrome $c$; Endo G, endonuclease G; $\mathrm{F}$, myocardial fibrosis; $\mathrm{CH}$, cardiac hypertrophy; HDAC, histone deacetylase; HF, heart failure; HT, hypertension; LVR, left ventricular remodeling; MI, myocardial infarction; MIS, myocardial ischemia; I/R, ischemia/reperfusion; LTCC, L-type $\mathrm{Ca}^{2+}$ channel; MFN1/2, mitofusins 1/2; MPTP, mitochondrial permeability transition pore; mTOR, mammalian target of rapamycin; RI, reperfusion injury; TNF, tumor necrosis factor; ROS, reactive oxygen species; t-BID, truncated BID; UPR, unfolded protein response Received 15.9.11; revised 31.10.11; accepted 08.11.11; Edited by RA Knight
} 


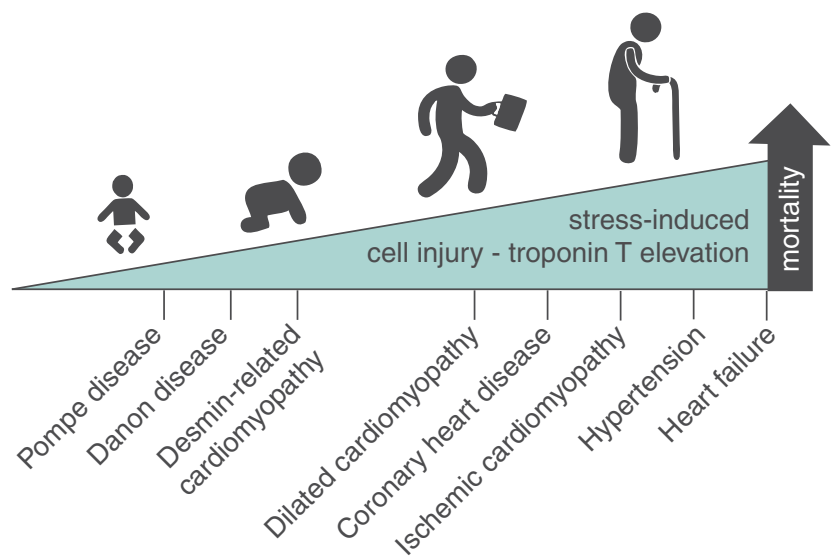

Figure 1 Aging, stress, and cell death progression. The cell injury marker troponin T increased during aging, as well as with different CVDs (de Lemos et al.) ${ }^{81}$

MI and worse cardiac function. ${ }^{9}$ If ischemia is prolonged, the autophagic response becomes dysfunctional, as evidenced by the existence of impaired autolysosomes.

During reperfusion, autophagy is upregulated further, even though the delivery of oxygen and nutrients is restored and AMPK is rapidly inactivated. 5,10 The continued activation of autophagy during reperfusion is qualitatively different than that in ischemia, especially in terms of mechanisms of induction. Stimulators, such as oxidative stress, mitochondrial damage/BNIP3, endoplasmic reticulum stress, and calcium overload, likely have more important roles in maintaining autophagy at a higher level during reperfusion. ${ }^{11}$ Although the available evidence is consistent that autophagy is protective under conditions of mild-to-moderate ischemia, the same cannot be said of autophagy elicited by reperfusion. Indeed, upregulation of autophagy can be either beneficial or detrimental in the context of $\mathrm{I} / \mathrm{R} .^{5,10}$

Recent evidence reveals that autophagosome clearance is impaired in I/R. Ischemia induces a decline in the levels of LAMP2, a protein critical for autophagosome-lysosome fusion, mediated by ROS-induced activation of serine and cysteine proteases; reperfusion induces upregulation of Beclin 1, which further impairs autophagosome processing, culminating in increased ROS generation, mitochondrial permeabilization, and cardiomyocyte death. ${ }^{12}$ More investigation is needed to clarify when and how elevated autophagy may be pro-survival to cardiac myocytes subjected to reperfusion injury.

\section{Autophagy in Response to MI}

There is limited information regarding autophagy in the context of MI. The most likely region where autophagy might be important is the sublethally injured, peri-infarct zone. In addition, autophagy may contribute to the more global process of postinfarction remodeling. Activation of AMPK by metformin blunted development of HF induced by MI, and inhibiting $\mathrm{mTOR}$ led to reduced remodeling and improved cardiac function after MI. ${ }^{13}$ Moreover, STAT1 deficiency is protective by enhancing autophagy in an ex vivo model of MI. ${ }^{14}$ However, the possible role of autophagic flux in the heart

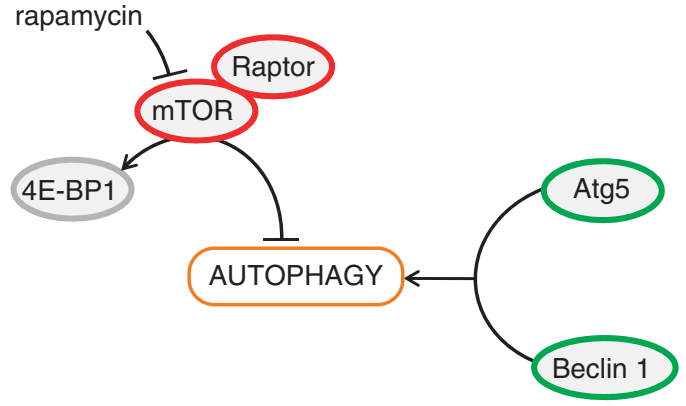

Figure 2 Schematic overview of the regulators of autophagy described in this section: Atg5 and Beclin 1 - components of the core autophagic machinery; mTOR and Raptor are components of the mTOR complex 1, an upstream repressor of autophagy; rapamycin - an inhibitor of mTOR (activates autophagy by releasing mTOR-mediated inhibition)

was not examined in these studies. Although these data suggest that agents known to regulate pathways that augment autophagy were protective, direct evidence is lacking regarding the specific role that autophagy has in $\mathrm{MI}$.

\section{Autophagy in Response to Cardiac Hypertrophy and HF}

In response to hemodynamic stress, such as pressure overload, the heart hypertrophies. Cardiac hypertrophy $(\mathrm{CH})$ is thought to be an adaptive process initially; however, it becomes detrimental to cardiac function if left unchecked. $\mathrm{CH}$ is a major, independent risk factor for systolic dysfunction and clinical HF. ${ }^{15}$ In HF patients, cardiac myocyte death with autophagic features occurred at a rate of $0.03 \%$ in humandilated cardiomyopathy $(\mathrm{C})$, as compared with $0.002 \%$ for apoptotic cell death. ${ }^{16}$ Together, these lines of evidence support the notion that autophagy participates in the pathogenesis of HF. The specific role of autophagy, however, in the pathogenesis of $\mathrm{CH}$ and HF-related remodeling is less clear.

The strongest evidence that autophagy facilitates development of pathological hypertrophy derives from genetic manipulations of the core autophagic machinery in mouse models. ${ }^{17,18}$ In contrast, several lines of evidence highlight the fact that autophagy can have an anti-hypertrophic role. The latter notion, however, requires additional corroboration, as it relies largely on indirect pharmaceutical manipulations of autophagy via upstream pathways. ${ }^{19-21}$ Here, we will briefly detail the studies supporting both concepts (see Figure 2 for an overview of major regulators of autophagy targeted in these studies).

$\mathrm{CH}$ was attenuated in Beclin 1 haploinsufficient hearts. Overexpression of Beclin 1 led to exacerbated hypertrophic growth in response to pressure overload. ${ }^{18}$ Importantly, a recent study by our group suggested that autophagy is necessary for the process of $\mathrm{CH}$. In this study, moderate pressure overload that induces $\mathrm{CH}$ also activated autophagy, and blocking this process inhibited pathological heart remodeling. RNAi-dependent knockdown of ATG5 and Beclin 1 attenuated the growth response induced by hypertrophic agonists. $^{17}$ 
Conversely, inhibition of mTOR, an upstream repressor of autophagy, blunts $\mathrm{CH}$, both clinically and in an animal model.20,22 However, the status of autophagy in these patients and animal hearts was not tested following treatment with rapamycin. ${ }^{20,22}$ Inactivation of cardiac mTOR was also associated with marked elevation of apoptosis and declines in myocardial function and accelerated progression to $\mathrm{HF}^{21}$ This could be rescued by deletion of a direct target of mTOR, 4E-BP1, although without notable changes in autophagy, suggesting that this process may not be a major contributor to the development of HF in these animals; rather, inhibition of protein synthesis may be the primary mechanism. In accordance, cardiomyocyte-specific inactivation of Raptor, a component of the mTOR complex 1 , induces dilated $C$ and high mortality within 6 weeks, with increases in apoptosis and autophagy. This evidence demonstrates a specific role of mTOR in preserving cardiac function. ${ }^{19}$

An emerging concept of an optimal, 'adaptive zone' of autophagic activation suggests an explanation of all this seemingly conflicting evidence. According to this concept, too much or too little autophagy may lead to increased hypertrophy and heart dysfunction. Supporting this, the conditional loss of function of Atg5 in adult mice led to rapid progression to hypertrophy and cardiac dysfunction in the absence of pressure overload. ${ }^{23}$

It may seem counterintuitive that blocking a catabolic pathway inhibits cardiac growth. However, cardiac myocytes are not quiescent structures; their components, including sarcomeres and mitochondria, are highly dynamic and constantly turning over. Indeed, the phenomenon of activation of both anabolic and catabolic processes during development of $\mathrm{CH}$ was observed long ago. However, the specific role of autophagy as a part of the catabolic process in $\mathrm{CH}$ has only recently started to surface. One day, it may emerge as a target for $\mathrm{CH}$ and HF therapy.

\section{Translational Implications in Cardiac Autophagy}

Modulation of the autophagic pathway may represent a future therapeutic target in heart disease. However, the complex nature of autophagic mechanisms and the lack of autophagyspecific inducing and blocking agents all contribute to limiting its therapeutic application. Agents such as metformin and rapamycin, an AMPK activator and mTOR inhibitor, respectively, have been tested in clinical settings for purposes other than autophagy. Metformin is used commonly in patients with diabetes, and its use diminishes all-cause mortality and $\mathrm{MI}^{24}$ More recently, animal models of ischemia and $I / R$ have reported beneficial effects of metformin by decreasing infarct size and blunting HF. ${ }^{25}$ Other medications used in MI, such as $\beta$-blockers (e.g., propranolol) and calcium channel blockers (e.g., verapamil), were examined more than 20 years ago. ${ }^{26,27}$ These studies found that the $\beta$-adrenergic agonist isoproterenol inhibited autophagy; ${ }^{27}$ and propranolol and verapamil had the opposite effect. ${ }^{26}$ These actions, however, were rather short lived, lasting only $10 \mathrm{~min} .^{26,27}$ The long-term impact on autophagy of $\beta$-blockers and calcium channel antagonists are unknown and potentially clinically relevant, as patients typically use them chronically to control blood pressure and symptoms from ischemic heart disease.
On the other hand, the $\alpha 1$-adrenergic receptor agonist phenylephrine increases cardiac myocyte autophagy. ${ }^{17}$

Autophagy can be activated by caloric restriction. ${ }^{28}$ In animal models, caloric restriction attenuates age-related changes in the heart, including hypertrophy, myocardial fibrosis, shifts in myosin isoform composition, histological changes, apoptosis, and the deterioration of chronotropic and inotropic responses to adrenergic stimulation. ${ }^{28}$ In humans, echocardiographic studies have shown that caloric restriction improves diastolic function in healthy nonobese humans in conjunction with reductions in indices of myocardial stiffness. ${ }^{28}$ It is apparent that more research is needed before any conclusion can be drawn regarding the exact role autophagy has in ischemia and I/R, so that agents specifically designed as autophagy inducers or inhibitors can be considered clinically.

Recent work has provided insight into how autophagy contributes to $\mathrm{CH}$. Evidence supports the notion that activation of autophagy is required for both myocyte growth and to maintain homeostasis in an enlarged, hypertrophied myocyte. Histone deacetylase (HDAC) inhibitors suppress the maladaptive autophagic response, contributing to their antihypertrophic effects and leading to improved cardiac function. ${ }^{17}$ Indeed, increased autophagic activity may be a universal feature of $\mathrm{C}$, including chemotherapy-induced $\mathrm{C}$ and HF. The clinical relevance of HDAC inhibitors and autophagy in the heart is potentially significant, as these agents are currently used in patients as cancer chemotherapy. Conceivably, they are in a unique position to kill cancer cells and protect the heart at the same time.

In summary, the role of autophagy is intricate, and its contribution to heart disease is complex. Many aspects are still debated and actively investigated. However, maintenance of a balance of autophagy is critical, not too much and not too little (Figure 3).

\section{Apoptosis}

Apoptosis is mediated by two pathways, the extrinsic and the intrinsic pathways, and both have been described in cardiac myocytes. ${ }^{1}$ The extrinsic apoptotic pathway can be triggered by FAS ligand, tumor necrosis factor (TNF)- $\alpha$, or TRAIL. Both FAS and TNF receptor I are expressed in cardiac myocytes and have been implicated in cardiovascular pathology. ${ }^{1}$ TRAIL has also been reported to be released by cardiac myocytes, ${ }^{29}$ but no further information is available about TRAIL and the heart. Cardiac myocyte-specific overexpression of TNF- $\alpha$ in transgenic mice provoked dilated $\mathrm{C}$ and $\mathrm{HF},{ }^{30}$ suggesting that activation of the death receptor pathway by TNF- $\alpha$ is harmful to the heart (Figure 4).

The mitochondrion is the primary organelle involved in mediating the intrinsic apoptotic pathway. In cardiac myocytes, mitochondria are located at intermyofibrillar spaces and underneath the sarcolemma. This strategic distribution of mitochondria allows for efficient ATP supply to the highenergy demand, continuously contracting cardiac myocyte. However, because mitochondria can also contribute to cell death in response to multiple stresses, cardiac myocytes have developed special strategies to achieve strict control over the intrinsic apoptotic pathway. ${ }^{1,31}$ Cardiac myocytes express 




Figure 3 The Goldilocks rule of autophagy in heart disease. Autophagy is a dynamic process. The relationship between autophagy and heart disease is complex. Although basal autophagy is critical to maintain cellular and whole-body homeostasis, both increases and decreases in autophagy to excessive degree can be maladaptive. In $\mathrm{CH}, \mathrm{HF}$, and I/R, autophagic flux is abnormally elevated, contributing to cardiac dysfunction. With aging, Pompe disease, and Danon disease, autophagic activity and processing are attenuated, perturbing cellular homeostasis and contributing to cardiac disease. Animal models have been studied extensively to evaluate the role of autophagy in heart disease with either increases (Beclin $1 \mathrm{tg}$ ) or decreases (Atg5 KO, Beclin 1 het) in autophagic activity



Figure 4 Apoptotic pathway in cardiac myocytes. In the extrinsic pathway, death receptor activation by a death ligand induces death-inducing signaling complex (DISC) formation and casp 8 activation, which in turn activates casp 3 . This pathway can also activate the intrinsic pathway by the proteolysis of BID to t-BID by casp 8 and interaction of $t-B I D$ with BAX in the mitochondria. Pro-apoptotic BAX/ BAK induces cyto $c$, Smac/DIABLO, AIF, and Endo G release from the mitochondria. Cyto $c$ with Apaf1 and casp 9 form the apoptosome with activation of casp 9. Casp activity is regulated by the endogenous casp inhibitor XIAP. Cardiac myocytes are naturally resistant to apoptosis due to their low-level expression of Apaf1 and casps and high levels of XIAP various members of the BCL2 family, several of which are transcriptionally regulated in heart disease, including antiapoptotic and pro-apoptotic BCL2 proteins. ${ }^{32}$

Cardiac myocytes express low levels of Apaf1, and a consequence of this low Apaf1 activity is the engagement of strict control of caspase (casp) activation by endogenous XIAP. ${ }^{33}$ In fact, direct microinjection of cytochrome $c$ (cyto $c$ ) into cardiac myocytes was not sufficient to induce apoptosis. $^{33}$ This observation is consistent with studies showing substantial translocation of cyto $c$ into the cytosol, without much detectable apoptosis in human cardiomyopathic hearts. ${ }^{34}$ Downregulation of XIAP and cIAP1/2 in cardiac myocytes within the failing myocardium has been suggested to contribute to increased cardiac myocyte apoptosis. ${ }^{34}$ Transgenic mice overexpressing clAP2 had reduced infarct size and fewer TUNEL-positive cells after I/R ${ }^{35}$ IAPs can also be inhibited by SMAC/DIABLO and OMI/HTRA2, and inhibition of OMI/HTRA2 reduced apoptosis and infarct size in rat after I/R. ${ }^{36}$

\section{Mitochondria in Cardiac Myocyte Apoptosis}

It has been suggested that activation of the mitochondrial apoptotic pathway leading to executioner casp activation is relevant in heart injury. ${ }^{1}$ The notion of participation of casp activation in adult cardiac myocyte apoptosis emerged from studies using immunofluorescence microscopy ${ }^{16}$ and casp inhibitors. ${ }^{37}$ Bahi et al. ${ }^{38}$ demonstrated that cardiomyocyte levels of all casps decrease with age, and they are very low in adult cardiac cells. Recently, Bae et al. ${ }^{39}$ reported that apoptosis can be induced in the heart lacking casp activation via casp-independent pathways, probably through apoptosisinducing factor (AIF). Both the intrinsic and extrinsic pathways can be inhibited by the cytoprotective protein apoptosis repressor with caspase recruitment domain (ARC). ARC inhibits the extrinsic pathway by interacting with casp 8 and components of the death-inducing signaling complex, such as FADD, whereas inhibition of the intrinsic pathway is mediated by blocking BAX activation and mitochondria translocation. ${ }^{40}$

AIF is anchored by its $\mathrm{N}$ terminus to the mitochondrial inner membrane, with its $C$ terminus oriented toward the intermembrane space. AIF is required for oxidative phosphorylation and for the assembly and/or stabilization of respiratory complex $1 .{ }^{41}$ Upon induction of apoptosis, AIF is cleaved and released into the cytosol, where it translocates to the nucleus and mediates chromatin condensation and large-scale DNA fragmentation. ${ }^{41}$ However, this well-known pro-apoptotic action of AIF is in conflict with the observation that AIF is essential for the maintenance of normal heart function and its inactivation results in dilated $\mathrm{C} .{ }^{42}$ Moreover, cardiac myocytes isolated from a mouse model with $80 \%$ reduction in AIF levels manifested increased cell death induced by oxidative stress, and the hearts of these mice displayed enhanced ischemic damage after in vivo I/R. ${ }^{43}$ Although it has been described that AIF is released from cardiac myocyte mitochondria during $\mathrm{I} / \mathrm{R}$, its contribution to I/R-induced apoptosis was discounted. ${ }^{38}$ However, AIF has been implicated in cardiac myocyte death induced by oxidative stress and HF. ${ }^{44}$

Endonuclease $\mathrm{G}$ (Endo $\mathrm{G}$ ) is a nuclear-encoded endonuclease localized to the intermembrane space of mitochondria. 
In cardiac myocyte apoptosis, Endo $G$ translocates to the nucleus, where it cleaves DNA. In heart and cultured cardiac myocytes, Endo $G$ has a role in I/R-mediated cell death. ${ }^{38}$ Activation of the intrinsic pathway by the extrinsic apoptotic pathway can take place through casp-8-dependent cleavage of BCL2-interacting protein (BID) to truncated BID (t-BID). The C-terminal fragment of t-BID subsequently translocates to the mitochondrial outer membrane, where it presumably activates the intrinsic pathway. This pathway is operative in the heart. ${ }^{1}$

\section{Mitochondrial Dynamics and Apoptosis}

Mitochondria exist as a complex, interconnected, and highly dynamic network characterized by the ongoing and counterbalanced events of mitochondrial fusion and fission. ${ }^{45}$ Mitochondrial fission is regulated by DRP-1 and FIS1, whereas mitochondrial fusion is controlled by mitofusins $1 / 2$ (MFN1/2) and OPA1. ${ }^{45}$ Changes in the mitochondrial morphology of cardiac myocytes have been reported in several heart diseases. ${ }^{46}$ Fragmentation of the mitochondrial network in response to apoptotic stimuli is a frequent finding observed in cardiac myocytes. ${ }^{47}$ Loss of integrity of the mitochondrial membrane is mediated by a complex process that involves DRP-1, MFN2, and the pro-apoptotic protein BAX. ${ }^{45,46}$ Decreases in the abundance of MFN2 is associated with an increase in mitochondrial fragmentation and cyto $c$ release, pointing to a protective role of MFN2 against apoptotic death. ${ }^{47}$

Recently, emerging evidence suggests that the unfolded protein response (UPR) has important roles in pressure overload-triggered HF. ${ }^{48}$ UPR markers, including GRP78, calreticulin and GRP94, are significantly upregulated in mouse heart in the setting of pressure overload. ${ }^{48}$ Angiotensin II administration can induce ER stress and apoptosis in cultured cardiomyocytes. Furthermore, CHOP activation in pressure overload contributes to $\mathrm{CH}$ and $\mathrm{HF} .{ }^{49} \mathrm{Fu}$ et al. ${ }^{49}$ showed that CHOP-deficient animals manifested less $\mathrm{CH}$, fibrosis, and cardiac dysfunction in the setting of pressure overload. These studies highlight the critical role of ER stress in $\mathrm{CH}$ and $\mathrm{HF}$.

\section{Apoptosis in HF}

Apoptosis is rare in normal human myocardium, with a reported prevalence of approximately one TUNEL-positive cardiac myocyte per $10000-100000$, that is, $0.01-0.001 \%$. In human failing hearts of New York Heart Association class III-IV, apoptotic cells are detectable in the range of $0.12-0.70 \%{ }^{50}$ In all reported cases, apoptosis levels were substantially lower than $1 \%$. Because the limited ability of cardiac myocytes to proliferate, low levels of apoptosis can still have profound effects. Mani ${ }^{51}$ has postulated that an apoptotic rate of $0.1 \%$ would be expected to result in a $\sim 37 \%$ loss in cardiac myocyte number over a year. This issue was addressed by generating transgenic mice with cardiac myocyte-specific expression of an inducible casp $8 .^{52}$ These transgenic mice developed severe, dilated C over 8 weeks and died within 2-6 months, manifesting disease progression that was markedly accelerated as compared with healthy wild-type mice that exhibited apoptotic rates of $\sim 0.002 \%$. ${ }^{52}$
This finding suggests that a very low, albeit elevated, rate of apoptosis can be an important component of HF pathogenesis.

\section{Apoptosis in MI and I/R}

Because of the intrinsically low levels of Apaf1 and casps in cardiac myocytes, nonmyocyte cells within the heart may be more susceptible to apoptosis. This, in turns, complicates the study of cardiac myocyte apoptosis in whole heart. Permanent coronary occlusion induced maximum cardiac myocyte apoptosis at $4.5 \mathrm{~h}$, whereas necrosis peaked at $24 \mathrm{~h} .{ }^{53}$ Reperfusion appeared to accelerate the timing of apoptosis as compared with permanent occlusion. ${ }^{54}$

Mice that lack FAS (Ipr mice) exhibited a decrease in cardiac myocyte apoptosis in models of doxorubicin toxicity, ${ }^{55}$ as well as marked reductions in infarct size following I/R. ${ }^{56}$ However, deletion of either TNFR1 or TNFR2 does not affect infarct size. In contrast, deletion of both together resulted in significantly larger infarcts following permanent coronary occlusion. ${ }^{57}$ These results suggest that FAS, and not TNFR, is the major mechanism for activating the extrinsic apoptotic pathway during MI.

Cardiac myocyte-specific overexpression of BCL2 substantially reduces infarct size, cardiac myocyte apoptosis, and cardiac dysfunction following $\mathrm{l} / \mathrm{R} .^{58} \mathrm{BAX}$ deficiency reduces infarct size and cardiac dysfunction following I/R and following $\mathrm{MI}$ in mice ${ }^{59}$ Targeted deletion of PUMA reduced infarct size $\sim 50 \%$ in an ex vivo Langendorff $\mathrm{I} / \mathrm{R}$ model. ${ }^{60}$ Together, these results suggest that the intrinsic apoptosis pathway also has a central role in $\mathrm{MI}$

\section{Translational Implications of Cardiac Apoptosis}

To date, no clinical trial has been attempted to specifically block or inhibit apoptotic pathways during MI. However, in chronic HF, clinical trials have been carried out using compounds that deplete circulating TNF $-\alpha .{ }^{61}$ Etanercept is a recombinant human-soluble TNF receptor that binds to and neutralizes circulating TNF- $\alpha .{ }^{61}$ Despite encouraging results in small pilot trials, ${ }^{61,62}$ large multicenter trials of etanercept in moderate-to-severe HF did not demonstrate significant clinical benefit and even suggested that etanercept may adversely affect the course of the disease. ${ }^{61,63}$

Infliximab is a recombinant human-murine chimeric monoclonal antibody that specifically binds to and neutralizes TNF- $\alpha .{ }^{64}$ Infliximab improved left ventricular function and limited $\mathrm{HF}$ in TNF- $\alpha$ overexpressing transgenic mice. ${ }^{64}$ However, the ATTACH trial did not detect HF improvement, but rather uncovered a signal for adverse events in patients with moderate to severe HF. ${ }^{61,65}$ These disappointing results might be explained by the dual action of TNF- $\alpha$ : short-term beneficial but long-term harmful effects. More encouraging results have been obtained with pentoxifylline, a xanthinederived compound that directly modulates TNF- $\alpha$ mRNA expression, ${ }^{66}$ (as opposed to neutralizing circulating TNF- $\alpha$ ). A single-center, placebo-controlled trial of pentoxifylline reported improvement in left ventricular performance in idiopathic dilated C. ${ }^{67} \mathrm{~A}$ large multicenter trial is warranted. 


\section{Necrosis}

Necrosis is marked by distinct morphological changes, including cell swelling, plasma membrane damage, loss of ATP, and organelle swelling. Disruption of cell integrity and release of cellular contents trigger a secondary inflammatory response, with potential pathological consequences. ${ }^{1}$ Necrosis is mainly caused by physical or chemical trauma to the cell and has long been considered as passive and accidental cell death. ${ }^{68}$ Recently, however, emerging evidence suggests that a proportion of necrosis is regulated by serial signaling events in a controlled and orchestrated manner. Several terms have been introduced to describe this form of necrosis, such as programmed necrosis, casp-independent cell death, and necroptosis. ${ }^{69}$ A number of mechanisms has been proposed to explain the initiation and execution of necrosis, including death receptors, $\mathrm{ROS}, \mathrm{Ca}^{2+}$, and mitochondrial permeability transition pore (MPTP) opening (Figure 5). ${ }^{68,70}$

\section{Necrosis in HF}

A characteristic feature of $\mathrm{HF}$ is progressive dropout of cardiac myocytes and development of cardiac dysfunction. As noted above, early studies suggested that apoptosis serves as one critical factor contributing to cell demise in end-stage HF. However, later observations suggested that necrosis is more prominent in failing human heart, contributing several fold more to disease pathogenesis than apoptosis in both men and women. ${ }^{71}$ Mechanistically, sustained $\mathrm{Ca}^{2+}$ stress, together with persistent activation of adrenergic receptors, triggers necrotic cell death. Using inducible overexpression of the L-type $\mathrm{Ca}^{2+}$ channel (LTCC) specifically in cardiac myocytes, Nakayama et al. ${ }^{72}$ found that an increase of LTCC activity promoted progressive cell death, and coadministration of an adrenergic receptor agonist amplified this process. Importantly, cardiac myocytes were protected from cell death when cyclophilin D is absent, suggesting the MPTP and necrosis are involved. ${ }^{73,74}$ In contrast, forced expression of the anti-apoptotic protein BCL2 did not rescue cell death by $\mathrm{Ca}^{2+}$ overloading. These data suggest strongly that necrosis contributes to the progression of $\mathrm{HF}$, and that $\mathrm{Ca}^{2+}$ handling and MPTP opening may be critically involved.

\section{Necrosis in MI}

During $\mathrm{MI}$, activation of anaerobic glycolysis to provide ATP leads to accumulation of $\mathrm{H}^{+}$and acidosis. Ion pumps on the plasma membrane respond to remove excess $\mathrm{H}^{+}$in exchange of $\mathrm{Na}^{+}$. In response to elevated levels of intracellular $\mathrm{Na}^{+}$, the $\mathrm{Na}^{+} / \mathrm{Ca}^{2+}$ exchanger operating in reverse mode is less capable of removing intracellular $\mathrm{Ca}^{2+}$, culminating in increased cytoplasmic $\mathrm{Ca}^{2+}$ levels. The mitochondrial $\mathrm{Ca}^{2+}$ uniporter then transports $\mathrm{Ca}^{2+}$ into mitochondria. Increases in $\mathrm{Ca}^{2+}$ within this organelle induces $\mathrm{Ca}^{2+}$-dependent dehydrogenase activation, declines in $\mathrm{NADH}$ and electron flux through the electron transport chain, increased ROS, and decreases in ATP levels. As $\mathrm{Ca}^{2+}$ uptake into mitochondria dissipates mitochondrial membrane potential, eventually the increase in matrix $\mathrm{Ca}^{2+}$ reaches a plateau under hypoxic conditions due to limitation of the

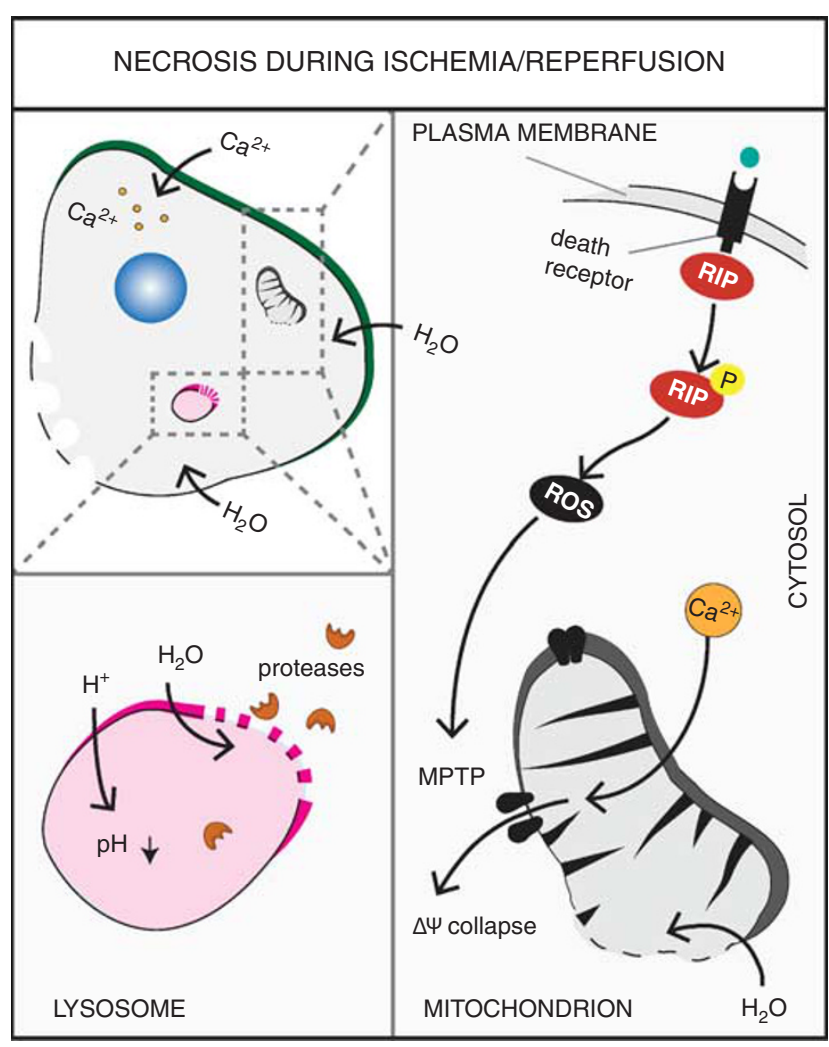

Figure 5 Necrosis pathways in cardiac myocytes. During certain cardiac pathologies, such as I/R, the action of cellular pumps is inhibited by ATP depletion, there is a consequent increase in $\mathrm{H}^{+}$and $\mathrm{Na}^{+}$, and the sodium-calcium exchanger (NCX) operates in reverse manner. Increased cytoplasmic $\mathrm{Ca}^{2+}$ leads to increased $\mathrm{Ca}^{2+}$ in the mitochondrial matrix along with elevated levels of ROS, culminating in MPTP opening, and necrosis. On the other hand, mitochondrial swelling and mitochondrial membrane rupture also produce necrosis. Moreover, increased $\mathrm{H}^{+}$ in the cytoplasm and inactivation of $\mathrm{H}^{+}$pumps elicit declines in lysosomal $\mathrm{pH}$, which results in overactivation of proteases such as cathepsins. The massive entry of water results in lysosomal swelling, membrane rupture, and release of proteases into the cytoplasm, which together with other activated proteases, such as calpains, digest different substrates, including cytoskeletal proteins, contributing to necrosis. Activation of death receptors, such as the TNF- $\alpha$ receptor, represents other necrosis pathways in cardiac myocytes under certain conditions such as HF. The activation of these receptors could lead to the activation of receptor-interacting protein (RIP), increased ROS, and necrosis. The massive inflow of water into the cell by the osmotic imbalance ultimately leads to cell swelling and rupture of the plasma membrane

proton gradient. Upon reperfusion, however, restoration of oxygen and ATP-generating capabilities quickly recovers ATP levels and mitochondrial membrane potential. These changes regenerate the required ion gradient for more $\mathrm{Ca}^{2+}$ entry into mitochondria, which causes long-lasting opening of MPTP regulated by cyclophilin $D$, and mitochondrial swelling leads ultimately to cellular necrosis. ${ }^{1}$

Some evidence implicates MPTP opening as a mechanistic link between myocyte necrosis and I/R injury. Involvement of MPTP in cardiac I/R responses was elegantly illustrated by the Molkentin and Tsujimoto groups. ${ }^{73,74}$ Using similar genetic approaches, they found that lack of cyclophilin $D$ protected cardiac myocytes from $\mathrm{Ca}^{2+}$ overload-induced cell death in vitro. Infarct size and lactate release from the heart were dramatically reduced in the mutant animals after I/R. 
Interestingly, pro-apoptotic protein-induced cyto $c$ release did not differ between wild-type and knockout mitochondria, suggesting that cyclophilin $\mathrm{D}$ does not have a critical role in apoptosis.

\section{Translational Implications of Necrosis}

Promising work on MPTP opening from in vitro tissue culture and in vivo animal studies has provided hints regarding therapeutic targets to protect the heart from necrosis. Cyclosporin is a potent inhibitor of MPTP. A pilot clinical trial by Piot et al. ${ }^{75}$ found that acute treatment with cyclosporin upon reperfusion at the time of percutaneous coronary intervention was associated with reduced infarct size and reduced creatine kinase and troponin I release. Although these results are encouraging and suggest that inhibition of MPTP is key in the protection against necrotic death during $\mathrm{I} / \mathrm{R}$, additional experimental work is needed to determine the contribution of other targets of cyclosporin, such as calcineurin or nitric oxide synthase (NOS), in this cardioprotection.

Necrostatin-1 is a selective inhibitor of necroptosis, a specialized pathway of programmed necrosis, targeting the kinase RIP1. ${ }^{76}$ In vitro studies using cancer cell lines reported protective effects of necrostatin-1 in TNF- $\alpha$ induced necrosis. More recently, the role of necrostatin- 1 in cardiac I/R has been evaluated. ${ }^{76} \mathrm{~A}$ bolus dose of necrostatin- 1 in wild-type mice at the time of coronary reperfusion dramatically reduced infarct size after I/R injury, whereas no protection was found in cyclophilin D-deficient animals. Necrostatin-1 may hold promise for consideration of clinical use.

Table 1 Autophagy, apoptosis, and necrosis interventions

\begin{tabular}{|c|c|c|c|c|}
\hline Type & Intervention & Model & Effect & Reference \\
\hline \multirow[t]{9}{*}{ Autophagy } & Dominant-negative AMPK & Transgenic mouse & $\begin{array}{l}\text { Attenuated autophagic response to ischemia with larger MI } \\
\text { and worse cardiac function }\end{array}$ & Russell et al. $^{9}$ \\
\hline & $\begin{array}{l}\text { Activation of AMPK with } \\
\text { metformin }\end{array}$ & Rat & Reduction of HF induced by MI & Buss et al. ${ }^{13} ;$ Yin et al. ${ }^{25}$ \\
\hline & STAT1 deficiency & Transgenic mouse & Enhanced autophagy that protects upon reperfusion & McCormick et al. ${ }^{14}$ \\
\hline & Atg5 knockout & Transgenic mouse & $\begin{array}{l}\text { Rapid progression to hypertrophy and cardiac dysfunction } \\
\text { with pressure overload }\end{array}$ & Nakai et al. $^{23}$ \\
\hline & $\begin{array}{l}\text { Beclin } 1 \text { heterozygous } \\
\text { disruption }\end{array}$ & Transgenic mouse & Decreased heart hypertrophy to pressure overload & Zhu et al. ${ }^{18}$ \\
\hline & $\begin{array}{l}\text { Beclin } 1 \text { overexpression } \\
\text { Propranolol ( } \beta \text {-blocker) and } \\
\text { verapamil (calcium channel } \\
\text { blocker) }\end{array}$ & $\begin{array}{l}\text { Transgenic mouse } \\
\text { Rat }\end{array}$ & $\begin{array}{l}\text { Exacerbated heart hypertrophy to pressure overload } \\
\text { Induction of autophagy }\end{array}$ & $\begin{array}{l}\text { Zhu et al. }{ }^{18} \\
\text { Bahro and Pfeifer }\end{array}$ \\
\hline & $\begin{array}{l}\text { Isoproterenol ( } \beta \text {-adrenergic } \\
\text { agonist) }\end{array}$ & Rat & Inhibition of autophagy & Pfeifer et al. ${ }^{27}$ \\
\hline & $\begin{array}{l}\text { Phenylephrine ( } \alpha 1- \\
\text { adrenergic agonist) }\end{array}$ & $\begin{array}{l}\text { Cultured rat } \\
\text { cardiomyocytes }\end{array}$ & Induction of autophagy & Cao et al. ${ }^{17}$ \\
\hline & Histone deacetylase & $\begin{array}{l}\text { Cultured rat } \\
\text { cardiomyocytes }\end{array}$ & Suppression of maladaptive autophagic response & Cao et al. ${ }^{17}$ \\
\hline \multirow[t]{9}{*}{ Apoptosis } & $\begin{array}{l}\text { Overexpression of clAP2 } \\
\text { Inhibition of OMI/HTRA2 } \\
\text { Caspase inhibition with } \\
\text { YVAD-cmk }\end{array}$ & $\begin{array}{l}\text { Transgenic mouse } \\
\text { Rat } \\
\text { Rat }\end{array}$ & $\begin{array}{l}\text { Reduced infarct size and TUNEL-positive cells after I/R } \\
\text { Reduction of apoptosis and infarct size after I/R } \\
\text { Reduced infarct size and TUNEL-positive cells } \\
\text { after I/R }\end{array}$ & $\begin{array}{l}\text { Chua et al. }{ }^{35} \\
\text { Bhuiyan and Fukunaga }{ }^{36} \\
\text { Holly et al. }{ }^{37}\end{array}$ \\
\hline & $\begin{array}{l}\text { Doxorubicin treatment of } \\
\text { caspase inhibitor CrmA in } \\
\text { overexpressing mice }\end{array}$ & Transgenic mouse & $\begin{array}{l}\text { Induction of apoptosis in hearts lacking caspase activation } \\
\text { via caspase-independent pathways, probably by AIF }\end{array}$ & Bae et al. ${ }^{39}$ \\
\hline & $\begin{array}{l}\text { Cardiac-specific expression } \\
\text { of inducible caspase } 8\end{array}$ & Transgenic mouse & $\begin{array}{l}\text { Presence of } 0.023 \% \text { of apoptosis, with development of } \\
\text { severe dilated cardiomyopathy over } 8 \text { weeks and death } \\
\text { after } 2-6 \text { months }\end{array}$ & Wencker et al. ${ }^{52}$ \\
\hline & FAS knockout & Transgenic mouse & $\begin{array}{l}\text { Decreased apoptosis upon doxorubicin treatment and } \\
\text { reduction of infarct size following l/R }\end{array}$ & $\begin{array}{l}\text { Nakamura et al. }{ }^{55} \text {; Lee } \\
\text { et al. }{ }^{56}\end{array}$ \\
\hline & $\begin{array}{l}\text { Cardiac-specific } \\
\text { overexpression of BCL2 }\end{array}$ & Transgenic mouse & $\begin{array}{l}\text { Reduction of infarct size, apoptosis and cardiac } \\
\text { dysfunction after I/R }\end{array}$ & Chen et al. ${ }^{58}$ \\
\hline & BAX knockout & Transgenic mouse & $\begin{array}{l}\text { Reduction of infarct size and cardiac dysfunction following } \\
\text { I/R and Ml }\end{array}$ & Hochhauser et al. ${ }^{80}$ \\
\hline & PUMA knockout & Transgenic mouse & $\begin{array}{l}\text { Reduction of infarct size in an ex vivo Langendorff } \\
\text { l/R model }\end{array}$ & Toth et al. ${ }^{60}$ \\
\hline & $\begin{array}{l}\text { Etanercept, a recombinant } \\
\text { human-soluble TNF receptor }\end{array}$ & Clinical trials & Nonsignificant clinical benefits & $\begin{array}{l}\text { Balakumar and Singh } \\
\text { Mann et }\end{array}$ \\
\hline & $\begin{array}{l}\text { Infliximab, a recombinant } \\
\text { chimeric TNF- } \alpha \text {-neutralizing } \\
\text { monoclonal antibody }\end{array}$ & Clinical trials & $\begin{array}{l}\text { Non-HF improvement and increased adverse effects in } \\
\text { patients with moderate-to-severe HF }\end{array}$ & Kadokami et al. ${ }^{64}$ \\
\hline \multirow[t]{3}{*}{ Necrosis } & Cyclophilin D knockout & Transgenic mouse & $\begin{array}{l}\text { Resistance to necrotic cell death induced by reactive } \\
\text { oxygen species and } \mathrm{Ca}^{2+} \text { overload and a high level of } \\
\text { resistance to l/R-induced cardiac injury }\end{array}$ & $\begin{array}{l}\text { Baines et al. }{ }^{73} \\
\text { Nakagawa et } \text { al. }^{74}\end{array}$ \\
\hline & $\begin{array}{l}\text { Acute treatment with } \\
\text { cyclosporin A, a MPTP } \\
\text { inhibitor, during } \\
\text { percutaneous coronary } \\
\text { angioplasty }\end{array}$ & Clinical trials & $\begin{array}{l}\text { Reduction of infarct size and reduced creatine kinase } \\
\text { and troponin I release }\end{array}$ & Piot et al. ${ }^{75}$ \\
\hline & Necrostatin-1 & Mouse & Reduction of infarct size after I/R & Lim et al. ${ }^{76}$ \\
\hline
\end{tabular}


Table 2 Patent applications related to autophagy, apoptosis, and necrosis for the treatment of cardiovascular diseases

\begin{tabular}{|c|c|c|c|c|}
\hline Type & Patent category & Therapeutic/Target & Remarks & Patent number \\
\hline \multirow[t]{5}{*}{ Necrosis } & Necrosis inhibitor & $\begin{array}{l}\text { 4-(4-Chlorobenzyl)-2-(hexahydro-1-methyl-1H- } \\
\text { azepin-4-yl)-1(2h)-phthalazinone }\end{array}$ & MIS & JP63218622 \\
\hline & Necrosis inhibitor & $\begin{array}{l}\text { Potassium channel activator, such as pinacidil } \\
\text { or cromakalim }\end{array}$ & $\mathrm{I} / \mathrm{R}$ & EP0351767 \\
\hline & Necrosis inhibitor & $\begin{array}{l}\text { 1,4-Benzoxazine derivative such as } \mathrm{Na}^{+} / \mathrm{H}^{+} \text {exchange } \\
\text { inhibitor }\end{array}$ & $\begin{array}{l}\text { MIS, cardiac dysfunction, } \\
\text { myocardial necrosis, } \\
\text { arrhythmia, RI, MI }\end{array}$ & US5597820 \\
\hline & Necrosis inhibitor & $\begin{array}{l}\text { Benzo[1,4]thiazine derivatives such as } \mathrm{Na}^{+} / \mathrm{H}^{+} \\
\text {exchange system inhibitor }\end{array}$ & MIS, MI, angina pectoris & W09813357 \\
\hline & Necrosis inhibitor & Benzothiophen-2-carbonylguanidine derivatives & $\mathrm{I} / \mathrm{R}$ & US2010004466 \\
\hline \multirow{11}{*}{$\begin{array}{l}\text { Necrosis } \\
\text { and } \\
\text { apoptosis }\end{array}$} & TNF- $\alpha$ inhibitor/antagonist & Human recombinant antibodies anti TNF- $\alpha$ & MIS & WO9729131 \\
\hline & TNF- $\alpha$ inhibitor/antagonist & Soluble TNF receptor & $\mathrm{HF}$ & W00059530 \\
\hline & TNF- $\alpha$ inhibitor/antagonist & Inhibition of TNF- $\alpha$ expression with adenosine & $\mathrm{CHF}$ & US6221851 \\
\hline & TNF- $\alpha$ inhibitor/antagonist & $\begin{array}{l}\text { Inhibition of TNF- } \alpha \text { expression with phosphodiesterase } \\
\text { type IV inhibitors }\end{array}$ & $\mathrm{CHF}$ & EP0995439 \\
\hline & TNF- $\alpha$ inhibitor/antagonist & Soluble TNF- $\alpha$ receptor & $\mathrm{CHF}$ & WO02080847 \\
\hline & TNF- $\alpha$ inhibitor/antagonist & Anti-TNF- $\alpha$ antibodies & $\begin{array}{l}\text { Heart pathologies } \\
\text { underlying excess TNF- } \alpha\end{array}$ & US2003180299 \\
\hline & TNF- $\alpha$ inhibitor/antagonist & $\begin{array}{l}\text { Anti-TNFR1 polypeptides based on antibody } \\
\text { single-variable domains }\end{array}$ & Heart necrosis & WO2010081787 \\
\hline & TNF- $\alpha$ inhibitor/antagonist & Bicyclosulfonyl acid compounds & $\mathrm{CHF}, \mathrm{I} / \mathrm{R}$ & US2010311741 \\
\hline & FAS inhibitor/antagonist & Antibody against human FAS & MI, MIS, I/R & US2010233157 \\
\hline & PARP inhibitor & $\begin{array}{l}\text { 3,6-Substituted 5-arylamino-1H-pyridine-2-one } \\
\text { derivatives }\end{array}$ & $\begin{array}{l}\text { MIS, diabetic myocardial } \\
\text { disease }\end{array}$ & US2007281948 \\
\hline & PARP inhibitor & Truncated PPAR inhibitor & $\mathrm{HF}$ & WO2009043953 \\
\hline \multirow[t]{29}{*}{ Apoptosis } & Caspase inhibitor & $\begin{array}{l}\text { Nicotinyl aspartyl ketones derivatives such as caspase- } \\
\text { 3-inhibiting compounds }\end{array}$ & $\mathrm{l} / \mathrm{R}$ & W00127085 \\
\hline & Caspase inhibitor & Isoxazoline derivatives & MIS & US6747050 \\
\hline & Caspase inhibitor & $\begin{array}{l}\text { Substituted } \alpha \text {-hydroxy acid such as potent inhibitors of } \\
\text { caspases and apoptotic cell death }\end{array}$ & $\mathrm{MI}, \mathrm{I} / \mathrm{R}, \mathrm{CHF}, \mathrm{C}$ & WO0116093 \\
\hline & Caspase inhibitor & Protein inhibitor of caspase 3 & $\begin{array}{l}\text { MIS, conduction } \\
\text { disturbance, chronic heart } \\
\text { diseases }\end{array}$ & JP2002355077 \\
\hline & Caspase inhibitor & $\begin{array}{l}\text { Inhibitor of caspase } 3 \text { or caspase-activated } \\
\text { desoxyribonuclease inhibitor }\end{array}$ & $\mathrm{HF}$ & US2003130216 \\
\hline & Caspase inhibitor & 2-Aminobenzamide derivatives & $\mathrm{MI}, \mathrm{CHF}, \mathrm{C}$ & US2003181388 \\
\hline & Caspase inhibitor & Dipeptide derivatives & $\mathrm{MI}, \mathrm{CHF}, \mathrm{C}$ & US2003181391 \\
\hline & Caspase inhibitor & Dipeptide derivatives & $\mathrm{MI}, \mathrm{CHF}, \mathrm{HF}, \mathrm{C}$ & US2004116355 \\
\hline & Caspase inhibitor & $\begin{array}{l}\text { Substituted piperidine, tetrahydroquinoline, or } \\
\text { tetrahydroisoquinoline }\end{array}$ & $\begin{array}{l}\text { MIS, MI, CHF, ATH, } \\
\text { coronary artery bypass } \\
\text { graft }\end{array}$ & WO0190070 \\
\hline & Caspase inhibitor & $\begin{array}{l}\text { Antisense for MIAP1, MIAP2, MIAP3, CIAP1, CIAP2, } \\
\text { XIAP, APAF1, RAIDD, and Diablo/SMAC }\end{array}$ & Cardiac disorders & US2004254136 \\
\hline & Caspase inhibitor & Cell wall of Chlorella pyrenoidosa & MIS & JP2005089324 \\
\hline & Caspase inhibitor & Pyridazinone derivatives & MIS & WO2008016239 \\
\hline & Caspase inhibitor & Danshensu derivatives & MIS & CN101607904 \\
\hline & Caspase inhibitor & Peptide derivatives & MIS & US2010184703 \\
\hline & Caspase inhibitor & Inhibition of OMI/HTRA2 & $\mathrm{HF}, \mathrm{MI}$ & US2010311772 \\
\hline & Caspase inhibitor & Isoxazoline derivative & MIS & WO2006090997 \\
\hline & $\begin{array}{l}\text { Intervention of Bcl2-related } \\
\text { proteins }\end{array}$ & Modified Bcl-xL & $\mathrm{MI}, \mathrm{I} / \mathrm{R}$ & WO2004110471 \\
\hline & $\begin{array}{l}\text { Intervention of Bcl2-related } \\
\text { proteins }\end{array}$ & Antisense oligonucleotide against BNIP3 & $\begin{array}{l}\text { Hypoxia-acidosis- } \\
\text { associated cardiac cell } \\
\text { death }\end{array}$ & WO2004009780 \\
\hline & Apoptosis inhibitor & 2-Substituted-4H-1,3-benzothiazine-4-one compounds & Heart diseases & US2003186971 \\
\hline & Apoptosis inhibitor & $\begin{array}{l}\text { Extracts of Radix salviae miltiorrhizae and Rhizoma } \\
\text { cnidii }\end{array}$ & $\begin{array}{l}\text { To inhibit apoptotic cardiac } \\
\text { cell death }\end{array}$ & KR20040000651 \\
\hline & Apoptosis inhibitor & $\begin{array}{l}\text { 3-[4-(4-Chlorophenyl)piperazin-1-yl]methyl- } \\
\text { 1H-pyrrolo[2,3-b]pyridine }\end{array}$ & MIS, C & EP1815866 \\
\hline & Apoptosis inhibitor & Human FAF1 protein inhibitor & MIS, HF, diabetic CVD, H & KR100818752 \\
\hline & Apoptosis inhibitor & Aminothiophene derivatives & MIS, diabetic CVD, HF, H & WO2008140214 \\
\hline & Apoptosis inhibitor & Recombinant human ARC protein & $\mathrm{C}, \mathrm{MI}, \mathrm{HF}$ & CN101307320 \\
\hline & Apoptosis inhibitor & 1,3-Benzothiazinone & Heart disease & US2009082343 \\
\hline & Apoptosis inhibitor & Tetrahydroisoquinolines & MI, MIS & US2009306130 \\
\hline & Apoptosis inhibitor & Deletion or silencing of midkine & I/R & US2010056437 \\
\hline & Apoptosis inhibitor & Extracts of Gramineae plant & MIS & US2010068315 \\
\hline & Apoptosis inhibitor & Corynantheine, the alkaloid extract from Uncaria & MIS & WO2010043109 \\
\hline \multirow[t]{5}{*}{ Autophagy } & Autophagy induction & 8-Methylchroman-7-ol derivatives & ATH, MIS & US2010173983 \\
\hline & Proteinopathy treatment & Farnesyl transferase inhibitor & $\begin{array}{l}\text { MI, MIS, vascular } \\
\text { hyperplasia, H, CHF, } \\
\text { restenosis, ATH, HT, } \\
\text { angina pectoris, }\end{array}$ & US2010160372 \\
\hline & Autophagy regulation & $\begin{array}{l}\text { Cell permeable Tat-Atg5K130R (inhibitor of autophagy) } \\
\text { and Tat-Beclin I (activator of autophagy) }\end{array}$ & $\mathrm{HF}, \mathrm{I} / \mathrm{R}$ & WO 2011106684 \\
\hline & Autophagy regulation & $\begin{array}{l}\text { Compounds that regulates ATG14L and rubicon, which } \\
\text { binds class III PI3K/Vps34-Beclin } 1 \text { complex }\end{array}$ & $\begin{array}{l}\text { Inflammatory cardiac } \\
\text { diseases }\end{array}$ & WO2010030936 \\
\hline & Autophagy induction & $\begin{array}{l}\text { Glycosylated anti-tumor ether lipids are small } \\
\text { molecules that induce and/or enhance autophagy in } \\
\text { cells }\end{array}$ & $\mathrm{I} / \mathrm{R}$ & WO2009092170 \\
\hline
\end{tabular}


Table 2 (Continued)

\begin{tabular}{|c|c|c|c|c|}
\hline Type & Patent category & Therapeutic/Target & Remarks & Patent number \\
\hline & Autophagy regulation & $\begin{array}{l}\text { Autophagy modulators identified by a high-throughput } \\
\text { phenotypic screen }\end{array}$ & MIS, I/R & WO2008122038 \\
\hline & $\begin{array}{l}\text { Cardiac autophagy death } \\
\text { regulation }\end{array}$ & $\begin{array}{l}\text { siRNA against ANT isoforms, which selectively } \\
\text { regulates autophagic cell death }\end{array}$ & MIS & US20060210535 \\
\hline & Autophagy regulation & A phosphorus-rapamycin analog, AP23573 & \multirow{2}{*}{$\begin{array}{l}\text { Restenosis, ATH, CVD, } \\
\text { cerebral vascular disease, } \\
\text { peripheral vascular disease } \\
\text { MIS, F, LVR }\end{array}$} & US20040073024 \\
\hline & $\begin{array}{l}\text { Anti-cardiac autophagic } \\
\text { degeneration/death }\end{array}$ & $\begin{array}{l}\text { Long-term administration of a colony-stimulating factor } \\
\text { (G-CSF) }\end{array}$ & & US2006051318 \\
\hline & Cardiac atrophy & $\begin{array}{l}\text { Agent that increases the expression of the run } 1 \text { gene } \\
\text { to prevent or decrease cardiac autophagy }\end{array}$ & $\begin{array}{l}\text { Treatment of a heart } \\
\text { condition whereby heart } \\
\text { muscle is destroyed }\end{array}$ & US2006003959 \\
\hline
\end{tabular}

Abbreviations: ATH, atherosclerosis; C, cardiomyopathy; CHF, congestive heart failure; CVD, cardiovascular disease; F, myocardial fibrosis; HF, heart failure; $\mathrm{HT}$, hypertension; I/R, ischemia/reperfusion; LVR, left ventricular remodeling; MI, myocardial infarction; MIS, myocardial ischemia; RI, reperfusion injury

\section{Stem Cell Therapy for HF}

$\mathrm{MI}$ and HF are associated with significant loss of cardiac myocytes, a process that has been thought to be irreversible. However, the discovery of tissue resident cardiac stem cells and the ability of exogenously delivered bone marrow (BM)derived stem cells to confer benefit have recently challenged this long held belief. ${ }^{77}$ These discoveries have stimulated basic and clinical research, with the aim of employing the regenerative properties of stem cells to repair damaged myocardium, improve cardiac function, and improve patient morbidity and mortality. ${ }^{77}$

Skeletal muscle cells have been considered as an alternative cell source for transplantation to improve cardiac function in animal models, which indeed succeeded. However, subsequent clinical trials revealed a significant signal for arrhythmic harm. ${ }^{78}$ Other types of cells, such as cultured cardiac stem cells, embryonic stem cells, or induced pluripotent stem cells, have also been considered as cellular sources for generating cardiac myocytes. ${ }^{79}$ Early reports showing that BM-derived adult stem/progenitor cells manifest greater plasticity than expected and can differentiate into cardiac myocytes raised the hope that BM-derived stem cells may improve both neovascularization and repair of the infarcted heart. Although there have been several basic research and numerous clinical studies showing that different subpopulations of BM-derived stem cells and other progenitor cells are capable of enhancing heart function, the signaling pathways involved and the extent to which progenitor cells are able to reestablish cardiac function in stage IV $\mathrm{HF}$ is extensively debated. ${ }^{77,79}$

\section{Conclusions and Perspectives}

Autophagy, apoptosis, and necrosis are major mechanisms in the pathogenesis of CVD. A summary of interventions showing the relevance of autophagy, apoptosis, and necrosis in cardiac myocyte cell death and/or heart diseases is depicted in Table 1. One day, clinical therapy targeting myocyte cell death is envisioned. Even though some translational applications have been tested already, manipulation of cardiac myocyte death is in its infancy. Currently, 55 patent applications related to the control of cardiac myocyte death/survival (5 in necrosis, 29 in apoptosis, 11 in apoptosis and/or necrosis, and 10 in autophagy) and its application to treatment of CVDs have been filed (Table 2). However, none of these products has emerged with success in clinical trials. Major translational challenges remain in this exciting area, but patients with heart disease are likely to benefit from these efforts.

\section{Conflict of Interest}

The authors declare no conflict of interest.

Acknowledgements. We thank the members from the Hill lab and Lavandero lab for helpful discussions. This work was supported by grants from the $\mathrm{NIH}$ (HL-075173, JAH; HL-080144, JAH; and HL-090842, JAH), AHA (0640084N, JAH), the AHA-Jon Holden DeHaan Foundation (0970518N, JAH), and the Fondo Nacional de Desarrollo Cientifico y Tecnologico: FONDECYT 1080436 and FONDAP 15010006 (SL). ZVW, ZP, and RT are supported by postdoctoral fellowships from the American Heart Association 10POST4320009 and FONDECYT 3110039 and 3110114 , respectively.

1. Whelan RS, Kaplinskiy V, Kitsis RN. Cell death in the pathogenesis of heart disease: mechanisms and significance. Annu Rev Physiol 2010; 72: 19-44.

2. Levine B, Kroemer G. Autophagy in the pathogenesis of disease. Cell 2008; 132: 27-42.

3. Marambio P, Toro B, Sanhueza C, Troncoso R, Parra V, Verdejo H et al. Glucose deprivation causes oxidative stress and stimulates aggresome formation and autophagy in cultured cardiac myocytes. Biochim Biophys Acta 2010; 1802: 509-518.

4. Lipinski MM, Hoffman G, Ng A, Zhou W, Py BF, Hsu E et al. A genome-wide siRNA screen reveals multiple $\mathrm{mTORC1}$ independent signaling pathways regulating autophagy under normal nutritional conditions. Dev Cell 2010; 18: 1041-1052.

5. Matsui Y, Takagi H, Qu X, Abdellatif M, Sakoda H, Asano T et al. Distinct roles of autophagy in the heart during ischemia and reperfusion: roles of AMP-activated protein kinase and Beclin 1 in mediating autophagy. Circ Res 2007; 100: 914-922.

6. Yan L, Vatner DE, Kim SJ, Ge H, Masurekar M, Massover WH et al. Autophagy in chronically ischemic myocardium. Proc Natl Acad Sci USA 2005; 102: 13807-13812.

7. French CJ, Taatjes DJ, Sobel BE. Autophagy in myocardium of murine hearts subjected to ischemia followed by reperfusion. Histochem Cell Biol 2010; 134: 519-526.

8. Hamacher-Brady A, Brady NR, Logue SE, Sayen MR, Jinno M, Kirshenbaum LA et al. Response to myocardial ischemia/reperfusion injury involves Bnip3 and autophagy. Cell Death Differ 2007; 14: 146-157.

9. Russell RR, 3rd, Li J, Coven DL, Pypaert M, Zechner C, Palmeri M et al. AMP-activated protein kinase mediates ischemic glucose uptake and prevents postischemic cardiac dysfunction, apoptosis, and injury. J Clin Invest 2004; 114: 495-503.

10. Hamacher-Brady A, Brady NR, Gottlieb RA. Enhancing macroautophagy protects against ischemia/reperfusion injury in cardiac myocytes. J Biol Chem 2006; 281: 29776-29787.

11. Gustafsson AB, Gottlieb RA. Autophagy in ischemic heart disease. Circ Res 2009; 104: 150-158.

12. Ma X, Foyil SR, Hill JA, Diwan A. Impaired autophagosome clearance contributes to cardiomyocyte death in ischemia-reperfusion injury. Unpublished Results 2011. 
13. Buss SJ, Muenz S, Riffel JH, Malekar P, Hagenmueller M, Weiss CS et al. Beneficial effects of mammalian target of rapamycin inhibition on left ventricular remodeling after myocardial infarction. J Am Coll Cardiol 2009; 54: 2435-2446.

14. McCormick J, Suleman N, Scarabelli TM, Knight RA, Latchman DS, Stephanou A STAT1 deficiency in the heart protects against myocardial infarction by enhancing autophagy. J Cell Mol Med 2011; e-pub ahead of print 29 March 2011; doi: 10.1111/j. 1582-4934.2011.01323.x.

15. Drazner MH, Rame JE, Marino EK, Gottdiener JS, Kitzman DW, Gardin JM et al. Increased left ventricular mass is a risk factor for the development of a depressed left ventricular ejection fraction within five years: the Cardiovascular Health Study. J Am Coll Cardiol 2004 43: 2207-2215.

16. Kostin S, Pool L, Elsasser A, Hein S, Drexler HC, Arnon E et al. Myocytes die by multiple mechanisms in failing human hearts. Circ Res 2003; 92: 715-724.

17. Cao DJ, Wang ZV, Battiprolu PK, Jiang N, Morales CR, Kong Y et al. Histone deacetylase (HDAC) inhibitors attenuate cardiac hypertrophy by suppressing autophagy. Proc Natl Acad Sci USA 2011; 108: 4123-4128

18. Zhu H, Tannous $P$, Johnstone JL, Kong $Y$, Shelton JM, Richardson JA et al. Cardiac autophagy is a maladaptive response to hemodynamic stress. J Clin Invest 2007; 117: 1782-1793.

19. Shende P, Plaisance I, Morandi C, Pellieux C, Berthonneche C, Zorzato F et al. Cardiac raptor ablation impairs adaptive hypertrophy, alters metabolic gene expression, and causes heart failure in mice. Circulation 2011; 123: 1073-1082.

20. Shioi T, McMullen JR, Tarnavski O, Converso K, Sherwood MC, Manning WJ et al. Rapamycin attenuates load-induced cardiac hypertrophy in mice. Circulation 2003; 107 : 1664-1670.

21. Zhang D, Contu R, Latronico MV, Zhang J, Rizzi R, Catalucci D et al. mTORC1 regulates cardiac function and myocyte survival through 4E-BP1 inhibition in mice. J Clin Invest 2010; 120: $556-563$.

22. Kushwaha SS, Raichlin E, Sheinin Y, Kremers WK, Chandrasekaran K, Brunn GJ et al. Sirolimus affects cardiomyocytes to reduce left ventricular mass in heart transplan recipients. Eur Heart J 2008; 29: 2742-2750.

23. Nakai A, Yamaguchi O, Takeda T, Higuchi $Y$, Hikoso S, Taniike $M$ et al. The role of autophagy in cardiomyocytes in the basal state and in response to hemodynamic stress. Nat Med 2007; 13: 619-624.

24. UK Prospective Diabetes Study (UKPDS) Group. Effect of intensive blood-glucose contro with metformin on complications in overweight patients with type 2 diabetes (UKPDS 34). Lancet 1998: 352: 854-865.

25. Yin M, van der Horst IC, van Melle JP, Qian C, van Gilst WH, Sillje HH et al. Metformin improves cardiac function in a nondiabetic rat model of post-MI heart failure. Am J Physiol 2011; 301: H459-H468.

26. Bahro M, Pfeifer U. Short-term stimulation by propranolol and verapamil of cardiac cellular autophagy. J Mol Cell Cardiol 1987; 19: 1169-1178.

27. Pfeifer U, Fohr J, Wilhelm W, Dammrich J. Short-term inhibition of cardiac cellular autophagy by isoproterenol. J Mol Cell Cardiol 1987; 19: 1179-1184.

28. Weiss EP, Fontana L. Caloric restriction - powerful protection for the aging heart and vasculature. Am J Physiol 2011; 301: H1205-H1219.

29. Liao $X$, Wang $X, G u Y$, Chen $Q$, Chen LY. Involvement of death receptor signaling in mechanical stretch-induced cardiomyocyte apoptosis. Life Sci 2005; 77: 160-174.

30. Kubota T, McTiernan CF, Frye CS, Slawson SE, Lemster BH, Koretsky AP et al. Dilated cardiomyopathy in transgenic mice with cardiac-specific overexpression of tumor necrosis factor- $\alpha$. Circ Res 1997; 81: 627-635.

31. Lee $Y$, Gustafsson AB. Role of apoptosis in cardiovascular disease. Apoptosis 2009; 14 536-548.

32. Condorelli G, Morisco C, Stassi G, Notte A, Farina F, Sgaramella G et al. Increased cardiomyocyte apoptosis and changes in proapoptotic and antiapoptotic genes bax and bcl-2 during left ventricular adaptations to chronic pressure overload in the rat. Circulation 1999; 99: 3071-3078

33. Potts MB, Vaughn AE, McDonough H, Patterson C, Deshmukh M. Reduced Apaf-1 levels in cardiomyocytes engage strict regulation of apoptosis by endogenous XIAP. J Cell Biol 2005; 171: 925-930.

34. Scheubel RJ, Bartling B, Simm A, Silber RE, Drogaris K, Darmer D et al. Apoptotic pathway activation from mitochondria and death receptors without caspase- 3 cleavage in failing human myocardium: fragile balance of myocyte survival? J Am Coll Cardiol 2002; 39: 481-488.

35. Chua CC, Gao J, Ho YS, Xiong Y, Xu X, Chen Z et al. Overexpression of IAP-2 attenuates apoptosis and protects against myocardial ischemia/reperfusion injury in transgenic mice. Biochim Biophys Acta 2007; 1773: 577-583.

36. Bhuiyan MS, Fukunaga K. Inhibition of HtrA2/Omi ameliorates heart dysfunction following ischemia/reperfusion injury in rat heart in vivo. Eur J Pharmacol 2007; 557 168-177.

37. Holly TA, Drincic A, Byun Y, Nakamura S, Harris K, Klocke FJ et al. Caspase inhibition reduces myocyte cell death induced by myocardial ischemia and reperfusion in vivo. $J \mathrm{Mol}$ Cell Cardiol 1999; 31: 1709-1715

38. Bahi N, Zhang J, Llovera M, Ballester M, Comella JX, Sanchis D. Switch from caspasedependent to caspase-independent death during heart development: essential role of endonuclease $\mathrm{G}$ in ischemia-induced DNA processing of differentiated cardiomyocytes. $J$ Biol Chem 2006; 281: 22943-22952.
39. Bae S, Siu PM, Choudhury S, Ke Q, Choi JH, Koh YY et al. Delayed activation of caspaseindependent apoptosis during heart failure in transgenic mice overexpressing caspase inhibitor CrmA. Am J Physiol 2010; 299: H1374-H1381.

40. Gustafsson AB, Tsai JG, Logue SE, Crow MT, Gottlieb RA. Apoptosis repressor with caspase recruitment domain protects against cell death by interfering with Bax activation. J Biol Chem 2004; 279: 21233-21238.

41. Daugas E, Susin SA, Zamzami N, Ferri KF, Irinopoulou T, Larochette $\mathrm{N}$ et al. Mitochondrionuclear translocation of AIF in apoptosis and necrosis. FASEB J 2000; 14: 729-739.

42. Joza N, Susin SA, Daugas E, Stanford WL, Cho SK, Li CY et al. Essential role of the mitochondrial apoptosis-inducing factor in programmed cell death. Nature 2001; 410: 549-554.

43. van Empel VP, Bertrand AT, van der Nagel R, Kostin S, Doevendans PA, Crijns HJ et al. Downregulation of apoptosis-inducing factor in harlequin mutant mice sensitizes the myocardium to oxidative stress-related cell death and pressure overload-induced decompensation. Circ Res 2005; 96: e92-e101.

44. Chen M, Zsengeller Z, Xiao CY, Szabo C. Mitochondrial-to-nuclear translocation of apoptosis-inducing factor in cardiac myocytes during oxidant stress: potential role of poly(ADP-ribose) polymerase-1. Cardiovasc Res 2004; 63: 682-688.

45. Parra V, Verdejo H, Del CA, Pennanen C, Kuzmicic J, Iglewski M et al. The complex interplay between mitochondrial dynamics and cardiac metabolism. J Bioenerg Biomembr 2011; 43: 47-51.

46. Kuzmicic J, del Campo A, Lopez-Crisosto C, Morales PE, Pennanen C, Bravo-Sagua R et al. Mitochondrial dynamics: a potential new therapeutic target for heart failure. Rev Esp Cardiol 2011; 64: 916-923.

47. Parra V, Eisner V, Chiong M, Criollo A, Moraga F, Garcia A et al. Changes in mitochondrial dynamics during ceramide-induced cardiomyocyte early apoptosis. Cardiovasc Res 2008; 77: $387-397$

48. Minamino T, Komuro I, Kitakaze M. Endoplasmic reticulum stress as a therapeutic target in cardiovascular disease. Circ Res 2010; 107: 1071-1082.

49. Fu HY, Okada K, Liao Y, Tsukamoto O, Isomura T, Asai M et al. Ablation of C/EBP homologous protein attenuates endoplasmic reticulum-mediated apoptosis and cardiac dysfunction induced by pressure overload. Circulation 2010; 122: 361-369.

50. van Empel VP, Bertrand AT, Hofstra L, Crijns HJ, Doevendans PA, De Windt LJ. Myocyte apoptosis in heart failure. Cardiovasc Res 2005; 67: 21-29.

51. Mani K. Programmed cell death in cardiac myocytes: strategies to maximize post-ischemic salvage. Heart Fail Rev 2008; 13: 193-209.

52. Wencker D, Chandra M, Nguyen K, Miao W, Garantziotis S, Factor SM et al. A mechanistic role for cardiac myocyte apoptosis in heart failure. J Clin Invest 2003; 111: 1497-1504.

53. Kajstura J, Cheng W, Reiss K, Clark WA, Sonnenblick EH, Krajewski S et al. Apoptotic and necrotic myocyte cell deaths are independent contributing variables of infarct size in rats. Lab Invest 1996; 74: 86-107.

54. Fliss H, Gattinger D. Apoptosis in ischemic and reperfused rat myocardium. Circ Res 1996 79: $949-956$

55. Nakamura T, Ueda Y, Juan Y, Katsuda S, Takahashi H, Koh E. Fas-mediated apoptosis in adriamycin-induced cardiomyopathy in rats: in vivo study. Circulation 2000; 102: 572-578.

56. Lee $\mathrm{P}$, Sata M, Lefer DJ, Factor SM, Walsh K, Kitsis RN. Fas pathway is a critical mediator of cardiac myocyte death and MI during ischemia-reperfusion in vivo. Am J Physiol 2003. 284: $\mathrm{H} 456-\mathrm{H} 463$

57. Kurrelmeyer KM, Michael LH, Baumgarten G, Taffet GE, Peschon JJ, Sivasubramanian N et al. Endogenous tumor necrosis factor protects the adult cardiac myocyte against ischemic-induced apoptosis in a murine model of acute myocardial infarction. Proc Nat Acad Sci USA 2000; 97: 5456-5461.

58. Chen Z, Chua CC, Ho YS, Hamdy RC, Chua BH. Overexpression of Bcl-2 attenuates apoptosis and protects against myocardial I/R injury in transgenic mice. Am J Physiol 2001; 280: $\mathrm{H} 2313-\mathrm{H} 2320$.

59. Hochhauser E, Cheporko Y, Yasovich N, Pinchas L, Offen D, Barhum $Y$ et al. Bax deficiency reduces infarct size and improves long-term function after myocardial infarction. Cell Biochem Biophys 2007; 47: 11-20.

60. Toth A, Jeffers JR, Nickson P, Min JY, Morgan JP, Zambetti GP et al. Targeted deletion of Puma attenuates cardiomyocyte death and improves cardiac function during ischemiareperfusion. Am J Physiol 2006; 291: H52-H60.

61. Balakumar $P$, Singh M. Anti-tumour necrosis factor- $\alpha$ therapy in heart failure: future directions. Basic Clin Pharmacol Toxicol 2006; 99: 391-397.

62. Bozkurt B, Torre-Amione G, Warren MS, Whitmore J, Soran OZ, Feldman AM et al. Results of targeted anti-tumor necrosis factor therapy with etanercept (ENBREL) in patients with advanced heart failure. Circulation 2001; 103: 1044-1047.

63. Mann DL, McMurray JJ, Packer M, Swedberg K, Borer JS, Colucci WS et al. Targeted anticytokine therapy in patients with chronic heart failure: results of the Randomized Etanercept Worldwide Evaluation (RENEWAL). Circulation 2004; 109: 1594-1602.

64. Kadokami T, Frye C, Lemster B, Wagner CL, Feldman AM, McTiernan CF. Anti-tumor necrosis factor- $\alpha$ antibody limits heart failure in a transgenic model. Circulation 2001; 104 1094-1097.

65. Chung ES, Packer M, Lo KH, Fasanmade AA, Willerson JT. Randomized, double-blind, placebo-controlled, pilot trial of infliximab, a chimeric monoclonal antibody to tumor necrosis factor-alpha, in patients with moderate-to-severe heart failure: results of the antiTNF Therapy Against Congestive Heart Failure (ATTACH) trial. Circulation 2003; 107 3133-3140. 
66. Bergman MR, Holycross BJ. Pharmacological modulation of myocardial tumor necrosis factor $\alpha$ production by phosphodiesterase inhibitors. J Pharmacol Exp Ther 1996; 279: 247-254.

67. Sliwa K, Woodiwiss A, Candy G, Badenhorst D, Libhaber C, Norton G et al. Effects of pentoxifylline on cytokine profiles and left ventricular performance in patients with decompensated congestive heart failure secondary to idiopathic dilated cardiomyopathy. Am J Cardiol 2002; 90: 1118-1122.

68. Vanlangenakker N, Vanden Berghe T, Krysko DV, Festjens N, Vandenabeele P. Molecular mechanisms and pathophysiology of necrotic cell death. Curr Mol Med 2008; 8 : 207-220.

69. Henriquez M, Armisen R, Stutzin A, Quest AF. Cell death by necrosis, a regulated way to go. Curr Mol Med 2008; 8: 187-206.

70. Kroemer G, Galluzzi L, Brenner C. Mitochondrial membrane permeabilization in cell death. Physiol Rev 2007; 87: 99-163.

71. Guerra S, Leri A, Wang X, Finato N, Di Loreto C, Beltrami CA et al. Myocyte death in the failing human heart is gender dependent. Circ Res 1999; 85: 856-866.

72. Nakayama $\mathrm{H}$, Chen $\mathrm{X}$, Baines $\mathrm{CP}$, Klevitsky $\mathrm{R}$, Zhang $\mathrm{X}$, Zhang $\mathrm{H}$ et al. $\mathrm{Ca}^{2+}$ - and mitochondrial-dependent cardiomyocyte necrosis as a primary mediator of heart failure. J Clin Invest 2007; 117: 2431-2444.

73. Baines CP, Kaiser RA, Purcell NH, Blair NS, Osinska H, Hambleton MA et al. Loss of cyclophilin $D$ reveals a critical role for mitochondrial permeability transition in cell death. Nature 2005; 434: 658-662.

74. Nakagawa T, Shimizu S, Watanabe T, Yamaguchi O, Otsu K, Yamagata $\mathrm{H}$ et al. Cyclophilin D-dependent mitochondrial permeability transition regulates some necrotic but not apoptotic cell death. Nature 2005; 434: 652-658.
75. Piot $\mathrm{C}$, Croisille $\mathrm{P}$, Staat $\mathrm{P}$, Thibault $\mathrm{H}$, Rioufol $\mathrm{G}$, Mewton $\mathrm{N}$ et al. Effect of cyclosporine on reperfusion injury in acute myocardial infarction. N Engl J Med 2008; 359: 473-481.

76. Lim SY, Davidson SM, Mocanu MM, Yellon DM, Smith CC. The cardioprotective effect of necrostatin requires the cyclophilin-D component of the mitochondrial permeability transition pore. Cardiovasc Drugs Ther 2007; 21: 467-469.

77. Mozid AM, Arnous S, Sammut EC, Mathur A. Stem cell therapy for heart diseases. Br Med Bull 2011; 98: 143-159.

78. Menasche $P$, Alfieri $O$, Janssens $S$, McKenna W, Reichenspurner $H$, Trinquart $L$ et al. The Myoblast Autologous Grafting in Ischemic Cardiomyopathy (MAGIC) trial: first randomized placebo-controlled study of myoblast transplantation. Circulation 2008; 117: 1189-1200.

79. Laflamme MA, Murry CE. Heart regeneration. Nature 2011; 473: 326-335.

80. Hochhauser E, Kivity S, Offen D, Maulik N, Otani H, Barhum Y et al. Bax ablation protects against myocardial ischemia-reperfusion injury in transgenic mice. Am J Physiol 2003; 284: H2351-H2359.

81. de Lemos JA, Drazner MH, Omland T, Ayers CR, Khera A, Rohatgi A et al. Association of troponin $T$ detected with a highly sensitive assay and cardiac structure and mortality risk in the general population. JAMA 2010; 304: 2503-2512.

Cell Death and Disease is an open-access journal published by Nature Publishing Group. This work is licensed under the Creative Commons Attribution-Noncommercial-No Derivative Works 3.0 Unported License. To view a copy of this license, visit http://creativecommons.org/licenses/by-nc-nd/3.0/ 